\title{
Consumer Legal Protection Principles of Billing Mechanism by Digital Financial Service Provider: a Prescriptive Fintech Law Study in Indonesia
}

\author{
${ }^{1}$ Teddy Prima Anggriawan, ${ }^{1}$ Lucianus Budi Kagramanto, ${ }^{1}$ Trisadini Prasastinah Usanti, \\ $\&^{2}$ Rifan Jefri Sunarsono \\ ${ }^{1}$ Civil Law Department, Law Faculty, Airlangga University, Indonesia \\ ${ }^{2}$ Management Department, Economic and Business Faculty, Airlangga University, Indonesia
}

Email: teddy.prima.anggriawan-2018@fh.unair.ac.id

\begin{abstract}
Financial Technology or Fintech currently grows rapidly in Indonesia. The total of loan disbursement reached 155,902.55 Million IDR in the end of 2020. Alongside with it's development this digital tool like two blades which has negative and positive aspects. This research tries to explore the philosophy of consumer protection in online lending practices and investigate the consumer protection in the online loan collection mechanism by digital financial service providers in Indonesia. Through using some theory and literatures such as the justice theory, consumer protection, economic and law morality, digital document and supported by several primary and secondary legal materials to explain and answer the research question. The research method is the prescriptive by combining the types of doctrinal, reform-oriented, and theoretical research. The results obtained by the author found similarities between dispute resolution from the perspective of the consumer protection act with the arbitration protection law and alternative dispute resolution which both provide legal certainty to the parties.
\end{abstract}

Keyword: Fintech, Justice Theory, Consumer Protection, economic and Law Morality, and Digital Document

\section{INTRODUCTION}

Humans are naturally social creatures (zoon politicon) in fulfilling their life needs with the result that they need each other. One of the needs that make humans need each other is financial needs. Human financial needs will be different from other human financial needs. To meet these financial needs, humans generally will do various ways that one of the ways is by lending and borrowing. After the 2008 crisis, the referral system changed, as the capacity of bank lending programs for small and medium enterprises (SMEs) shrank between 2008 and 2013 due to higher risk aversion at a time of slowing economic growth (Fenwick et al., 2018). Article 1754 in Burgerlijk Wetboek explains that lending and borrowing is an agreement given to another party for a certain amount of goods that are exhausted due to use or goods that can be replaced with the same conditions and types or in the form of money. In other words, this lending and borrowing activity must involve goods or money that has a certain amount or value, so that it can be returned with a certain amount or value. 
This lending and borrowing activity does not only occur between individuals but has now become a business where now this is indicated by the existence of financing companies and others. The bank also currently has a lending and borrowing program. Bearing in mind that Article 1 Paragraph 2 of the Law of the Republic of Indonesia Number 10 of 1998 concerning Amendments to Act Number 7 of 1992 concerning banking states that bank is a business entity that collects funds from the public in the form of deposits and distributes them to the public in the form of credit and or other forms in order to improve the standard of living of the people at large.

With the rapid development of technology, currently lending and borrowing activities can even be done with the help of technology. This is marked by the growing development of Financial Technology or commonly referred to as Fintech. According to The National Digital Research Center (NDRC), in Dublin, Ireland, Fintech is an innovation in financial services as an innovation in the financial sector that gets a touch of modern technology. (Santi, et al., 2016) This Fintech is known to be not a new thing, but has existed for a long time, namely in the 1950s. Until now, Fintech has become a technology-based business that competes and or collaborates with financial institutions. The financial technology (Fintech) as one of the forms of technology in the financial sector, is now attracting the attention of researchers not only in economics and business fields but also in the field of computer science, especially information systems (Gai et al., 2018). Fintech has been competing with traditional financial services, making the access easier by using internet technology and offering customer-centric services (Gomber et al., 2017). Currently, Fintech business models address funding, capital markets, wealth management, payments, and insurance services (Lee and Shin, 2018).

Some of Indonesia's challenges to administer the Fintech platform are geography and infrastructure development. Beside that policy makers are also facing additional problems such as platform viability, moral hazard, and borrower eligibility (Suryono et al., 2019). Online lending, or peer to peer (P2P) lending, is a practice of funding unrelated individuals ('partners') without going through commercial banks. P2P lending is carried out online through selfdeveloped credit checking tools for P2P lending companies and the platforms of various loan (Wang et al., 2015). In May 2021, the Financial Services Authority (OJK), the financial authority in Indonesia, the number of licensed and registered Fintech lending companies is 138 (one hundred and thirty-eight) organizers with details of 57 (fifty-seven) licensed providers and 81 (eighty-one) registered providers (OJK, 2021). However, based on data from the Directorate General of Informatics Applications, 4020 Fintech sites and applications have been handled and blocked by the Ministry of Communications and Informatics during August 2018 - December 2019 (Kominfo, 2020). Based on the OJK report, the accumulated amount of Fintech loaners in Indonesia in April 2021 reached 36,795,731 and the total of loan disbursement was 155,902 milion rupiah which increased time by time since 2018 (OJK, 2021) (see Table 1).

\begin{tabular}{|c|c|c|}
\hline \multicolumn{3}{|c|}{$\begin{array}{c}\text { Total of Loan Disbursement } \\
\mathbf{2 0 1 8} \mathbf{- 2 0 2 0} \text { (in Million Rupiah) }\end{array}$} \\
\hline Dec-18 & Dec-19 & Dec-20 \\
\hline IDR 22,666.07 & IDR 81,497.51 & IDR 155,902.55 \\
\hline
\end{tabular}

source: Indonesia Financial Service Authority, 2020 
One of the causes of this growth was because the Indonesian P2P lending application users helped and benefited by the speed of requests approved as an alternative than traditional funding did (Pohan et al., 2019). Moreover, in addition to mentioned value before, several literatures detected six core problems in P2P lending such as determination of borrower credit scores, investment decisions, information asymmetry, moral hazard, platform feasibility and immature regulations and policies for the protection of personal data (Suryono et al., 2019b). For this reason, each stakeholder (OJK, SWI, Kemenkominfo, and Fintech Association) is expected to immediately agree to the Fintech lending industry code of ethics (Pryanka, 2018).

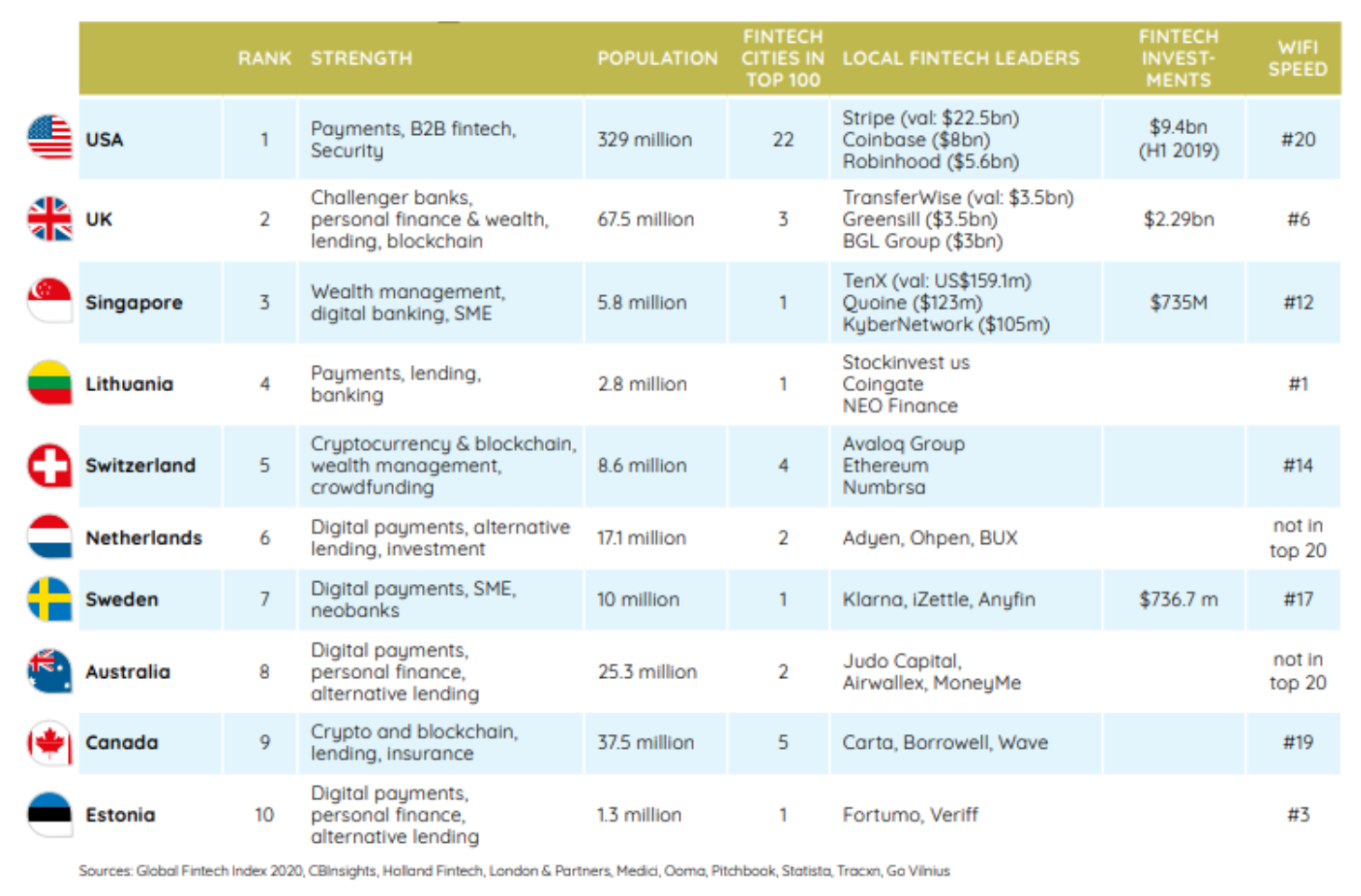

Picture 1. Fintech overview in the world

In Fintech lending and borrowing activities, it is known that there is an agreement between the lender (digital financial service provider) and the loan recipient. This is as explained in Article 20 of the Financial Services Authority Regulation Number 77 /POJK.01/2016 concerning Information technology-based lending and borrowing services which states thet the loan agreement between digital financial service providers and the borrower is stated in an electronic document. Thus, it is possible that in an agreement there will be parties who fail to carry out their achievements, or are referred to as defaults. For this reason, in the implementation of Fintech practices, legal protection for both lenders (collectors) and loan recipients is very necessary.

Legal protection is defined as a safeguarding of dignity, as well as the recognition of human rights that are owned by legal subjects (Desy, 2017). Such safeguards are based on legal provisions that have the authority to protect one thing from another. This legal protection applies to both parties to the agreement. In order for Fintech practice to be said healthy, legal protection 
for digital financial service providers and loan recipients must be balanced (Nurhafni and Bintang, 2018). Given that this Fintech practice adheres to the principle of engagement law which is namely the principle of freedom of contract that frees legal subjects to enter into and carry out agreements according to their wishes and needs as long as they fulfill the limiting signs (Muaziz and Busro, 2015), with the result that a violation of the respective legal protections vulnerable parties occur.

The digital financial service provider as regulated in Article 1 Paragraph 8 POJK No. 77/POJK.01/2016 concerning Information Technology-Based Lending and Borrowing Services are "...persons, legal entities, and/or business entities that have receivables due to an information technology-based lending and borrowing service agreement". Digital financial service providers are the parties who provide the money to be lent to the loan recipient with a certain agreement. Generally, there are many defaults committed by the recipient of the loan, such as not making installment payments at the specified time or paying late installments. There are even cases where the loan recipient does not make payments as agreed in the loan agreement. This practice then causes losses to the lender. For this reason, the protection of the rights of digital financial service providers must be enforced. An alternative way that is generally done to enforce legal protection for digital financial service providers is to apply sanctions to loan recipients as written in the agreed agreement. If the loan recipient does not have the good faith to complete his achievements, such as deliberately running away and not wanting to pay at all, legal action can be taken.

Legal protection is not only given to digital financial service providers, but also to loan recipients. The borrower in this case is the same as the consumer who in an agreement is the party most prone to violating the law on his rights. Loan recipients are generally parties who need this loan agreement to be implemented due to the encouragement of economic factors in particular. For this reason, generally loan recipients will not think too long at the beginning of making the agreement. And generally, the clauses in the agreement are made by the digital financial service providers, while the loan recipients are generally a weak position parties who tend to only accept and sign the contents of the agreement because they do not have the bargaining power to change the contents of the contract. In practice, to avoid the practice of clauses that are detrimental to one party, especially the loan recipient, then a regulation is issued to maintain the protection of service users (loan recipients) or what is commonly referred to as consumer protection with its regulations.

Fintech regulations in Indonesia are known to have been regulated in several laws and regulations such as POJK No. 77/POJK.01/2016 concerning Information Technology-Based Lending and Borrowing Services, PBI No. 18/40/PBI/2016 concerning the Implementation of Payment Transaction Processing, PBI No. 19/12/PBI/2017 concerning the Implementation of Financial Technology and Law no. 10/1998 concerning about Banking. Nevertheless, there are still many violations in its implementation.

Since 2016, LBH (Legal Aid Institution) Jakarta has received complaints from 283 people regarding online loans, especially regarding the collection mechanism which is considered intimidating and inhumane. YLKI (Indonesian Consumers Foundation) revealed that in the P2P lending case, OJK (Financial Fervices Authority) had freed up interest rates, fines, and daily commissions. As a result, consumer debt which is only 1 million IDR can soar to 10 million IDR even though it is only 2 months late. This clearly violates the rules in Article 30 of the Financial Services Authority Regulation Number: 1/POJK.07/2013 concerning consumer protection in the financial services sector. 
(1) The financial services providers are required to prevent their management, supervisors and employees from:

a. Enrich or benefit oneself or others,

b. Misuse the authority, opportunity, or facilities available to him because of his position or position, which can harm the consumers.

(2) Management and employees of financial services Business Actors are required to comply with the code of ethics in serving consumers, who have determined by each financial services business actor

(3) The financial services providers are required to be responsible to consumers for actions taken by third parties who act in the interest of the financial services business actor.

According to Article 26 of the Financial Services Authority Regulation Number 77/POJK.01/2016 concerning about the Information Technology-Based Borrowing-Lending Services, business actors (collection) have obligations including:

(1) Maintaining the confidentiality, integrity, and availability of personal data, transaction data, and financial data that it manages from the time the data is obtained until the data is destroyed.

(2) Notifying in writing to the owner of the personal data, transaction data, and financial data in the event of a failure in the protection of the confidentiality of personal data, transaction data, and financial data managed

In practice, there are also cases of collection, taking, retrieval and dissemination of personal data by online loan applications. Where in this case violates several articles as follows:

Article 27 of the Law of the Republic of Indonesia Number 19 of 2016 concerning about the Amendments to Law Number 11 of 2008 concerning about Information and Electronic Transactions explains that,

(1) Any person intentionally and without rights distributes and/or transmits and/or makes accessible electronic information and/or electronic documents that have contents that violate decency

(2) Any person intentionally and without rights distributes and/or transmits and/or makes accessible electronic information and/or electronic documents containing gambling content.

(3) Any person intentionally and without rights distributes and/or transmits and/or makes accessible electronic information and/or electronic documents that contain insults and/or defamation.

(4) Everyone intentionally and without rights distributes and/or transmits and/or makes electronic information accessible

(5) and/or electronic documents containing extortion and/or threats.

Article 29 of the Law of the Republic of Indonesia Number 19 of 2016 concerning about the amendments to Law Number 11 of 2008 concerning Electronic Information and Transactions explains that everyone intentionally and without rights sends electronic information and/or electronic documents containing th reats of violence or a personally aimed scare. Article 31 of the Financial Services Authority Regulation Number: 1/POJK.07/2013 concerning Consumer Protection in the Financial Services Sector explains that,

(1) Financial services businesses are prohibited in any way from providing data and/or information regarding their consumers to third parties. 
(2) The prohibition as referred to in paragraph (1) is exempted in the event that:

a. Consumers provide written consent; and/or

b. Required by legislation.

(3) The financial services providers obtain personal data and/or information of a person and/or group of people from other parties and the financial services providers will use such data and/or information to carry out their activities. The financial services providers are required to have a written statement that the other party has obtained written approval from the person and/or group of people to provide the said personal data and/or information to any party, including the financial services providers.

(4) The cancellation or partial amendment of the approval for the disclosure of data and/or information as referred to in paragraph (2) letter a shall be made in writing by the Consumer in the form of a statement letter.

The implementation of Fintech, such as billing mechanisms that are considered intimidating and inhumane, as well as digital financial service providers who collect, retrieve and disseminate personal data of loan recipients which reflects a non-compliance with existing legal protection regulations. Indonesia as a state of law, is obliged to provide justice for its citizens. This is confirmed in Article 28D of the 1945 Constitution of the Indonesia Republic, which is as follows:

(1) Everyone has the right to recognition, guarantee, protection, and fair legal certainty and equal treatment before the law.

(2) Everyone has the right to work and receive fair and proper remuneration and treatment in an employment relationship.

(3) Every citizen has the right to have equal opportunities in government.

(4) Everyone has the right to citizenship status.

Consumer rights are the right to basic needs, the right to vote, the right to information, the right to be heard, the right to protection, the right to education, the right to be served and the right to compensation (Ma'arif and Tanjung, 2003). In this case, consumer rights have also been regulated in consumer protection, which is expected to provide hope for the Indonesian people, to obtain protection for losses suffered by transactions of goods and services. UUPK (Law No. 8 of 1999 concerning Consumer Protection) guarantees legal certainty for consumers (Ahmad, 2007). This is also confirmed in Article 2 Consumer protection has also been guaranteed by the Government Regulation of the Republic of Indonesia Number 58 of 2001 concerning the Guidance and Supervision of the Implementation of Consumer Protection which states that the government is responsible for fostering the implementation of consumer protection which guarantees the acquisition of the rights of consumers and business actors and implementation of the obligations of consumers and business actors.

Related to the case as mentioned earlier, in the context of this research there is a set of laws that aim to provide consumer protection. The legal instrument meant is the Law of the Republic of Indonesia Number 8 of 1999 concerning Consumer Protection (hereinafter abbreviated as the Consumer Protection Law). In the preamble to the Consumer Protection Law, it is stated that producers must have responsibility for the products or business regulations they apply: "In order to increase the dignity of consumers, it is necessary to increase awareness, knowledge, concern, ability and independence of consumers to protect themselves and to develop responsible business". 
Not only that, for the sake of protecting consumers, violations caused in Fintech practices, especially as stated in Articles 27 and 29 of the Law of the Republic of Indonesia Number 19 of 2016 concerning Amendments to Law Number 11 of 2008 concerning Information and Electronic Transactions are known to have strict and firm sanctions. Sanctions for those who commit violations as described in Articles 27 and 29 of the Law of the Republic of Indonesia Number 19 of 2016 concerning Amendments to Law Number 11 of 2008 concerning Information and Electronic Transactions are known to have been regulated in Article 45 of the Law of the Republic of Indonesia Number 19 of 2016 concerning Amendments to Law Number 11 of 2008 concerning Information and Electronic Transactions as follows,

(1) Any person who knowingly and without rights distributes and/or transmits and/or makes accessible electronic information and/or electronic documents containing content that violates decency as referred to in Article 27 paragraph (1) shall be punished with imprisonment for a maximum of 6 (six) years and/or a maximum fine of $\mathrm{Rp}$. 1,000,000,000.00 (one billion rupiah).

(2) Any person who intentionally and without rights distributes and/or transmits and/or makes accessible electronic information and/or electronic documents containing gambling content as referred to in Article 27 paragraph (2) shall be punished with imprisonment for a maximum of 6 (six) years and/or a maximum fine of Rp. 1,000,000,000.00 (one billion rupiah).

(3) Any person who intentionally and without rights distributes and/or transmits and/or makes accessible electronic information and/or electronic documents containing insults and/or defamation as referred to in Article 27 paragraph (3) shall be punished with imprisonment for a maximum of 4 (four) years and/or a fine of a maximum of Rp. 750,000,000.00 (seven hundred and fifty million rupiah).

(4) Any person who intentionally and without rights distributes and/or transmits and/or makes accessible electronic information and/or electronic documents containing extortion and/or threats as referred to in Article 27 paragraph (4) shall be subject to imprisonment a maximum of 6 (six) years and/or a maximum fine of Rp. 1,000,000,000.00 (one billion rupiah).

(5) The provisions as referred to in paragraph (3) constitute a complaint offense.

For the sake of creating consumer protection, currently OJK (Financial Services Authority) has even formed a task force for the Development of Digital Economy and Financial Innovation to oversee Fintech players and at the end of 2016 to be precise on December 29, 2016, which finally issued a regulation regarding Fintech, namely OJK Regulation Number 77/POJK.01/ 2016 concerning Information Technology-Based Lending and Borrowing Services (LPMUBTI). The POJK contains rules regarding the provision, management, and operation of Information Technology-Based Lending and Borrowing Services. In this regulation, Fintech service providers are declared as other financial service institutions which can be in the form of limited liability companies or cooperatives. Nevertheless, there are still many problems or legal issues that occur along with the development of this Fintech.

Based on the description of the background of the problem above, it is important to conduct research related to the study of consumer protection law against 'Digital Billing'. The title of the research is "Consumer Legal Protection on Billing Mechanisms by Digital Financial Service Providers". 


\section{LITERATURE REVIEW}

\section{Theory of Justice}

According to John Rawls, justice is the first virtue of social institutions, because truth is a system of thought. A graceful and economical theory must be rejected or revised if it is not true, so are laws and institutions. No matter how efficient and well-ordered they must be reformed or abolished if they are unjust. Everyone has immunity founded on justice which even the welfare of society as a whole cannot be overridden. For this reason, justice denies that the loss of liberty for some is justified by the greater good of others. It is unlikely that the sacrifices imposed on some are disproportionate to the many benefits enjoyed by many (Rawls, 1999).

If there is no agreement on the concept of justice, there will be many arguments and opinions about the indicators of justice to be achieved or agreed upon, in other cases, if there are two parties who want to make a mutual agreement of course this will be a matter that must be discussed in depth to ensure that neither party who feel disadvantaged or benefited unilaterally. John Rawls explains justice or justice in a theory known as contract theory. To understand fairness through contract terminology, it must be remembered that it implies a certain level of abstraction. In particular, the content of the relevant contract is not to enter a certain society or to adopt a certain form of government, but to accept certain moral principles. Moreover, the undertaking in question is purely hypothetical: the view of the contract states that certain principles will be accepted under clear initial circumstances.

The advantage of contract terminology is that it conveys the idea that principles of justice can be understood as principles that rational persons would choose, and through this way, conceptions of justice can be explained and justified. The theory of justice is perhaps the most important part of rational choice theory. Further, the principles of justice deal with conflicting claims to the benefits won by social cooperation; applies to relationships among several people or groups. This becomes a problem if we look at the practice of agreements between consumers and business actors, many standard rules are applied so that consumers are considered to agree with what the business actors want.

The word "contract" denotes plurality as well as the condition that the appropriate distribution of benefits must be in accordance with principles that are acceptable to all parties. The condition of publicity for the principles of justice is also connoted by the phraseology of the contract. So, if these principles are the result of a contract/agreement, citizens have knowledge of the principles that others follow. When applied to the facts of the basic structure of society, the principles of justice must do two things:

a. The principle of justice must provide a concrete assessment of the fairness of institutions and institutional practices.

b. The principles of justice should guide us in developing policies and laws to correct injustices in the basic structures of certain societies.

According to Rawls in a book entitled the idea of justice, the deliberations in the imagined original position on the principles of justice demand the impartiality needed for fairness (Sen, 2010). to be achieved from a concept of justice. However, if we look at the problems that will be discussed in the concept of proportional justice and efficiency applied in standard agreements between business actors and consumers, it does not provide legal certainty to consumers because consumers have a weaker position and this of course is unfair and not suitable due to the existence of unfair position and the existence of the aggrieved party. As previously explained, 
since 2016, LBH (Legal Aid) Jakarta has received complaints from 283 people regarding online loans, especially regarding the collection mechanism which is considered intimidating and inhumane. YLKI (Indonesian Consumers Foundation) revealed that in the P2P lending case, the OJK (Financial Service Authority) had released the amount of interest rates, fines, and daily commissions. As a result, consumer debt which is only Rp. 1 million can soar to Rp. 10 million even though it is only 2 months late. This clearly violates the rules in Article 30 of the Financial Services Authority Regulation Number: 1/POJK.07/2013 concerning Consumer Protection in the Financial Services Sector. In practice, there are also cases of collection, collection, retrieval and dissemination of personal data by online loan applications. The implementation of Fintech, such as billing mechanisms that are considered intimidating and inhumane, as well as digital financial service providers who collect, retrieve and disseminate personal data of loan recipients reflect a non-compliance with existing legal protection regulations. Indonesia as a state of law, is obliged to provide justice for its citizens.

The principle of justice in law in general will make the community as a subject who asks for fair treatment to the state as law enforcers and government implementers. This is supported by Hart's opinion that the general principle of justice in law is equality and inequality. This means that similar things are treated in the same way, while different things are treated in different ways. This view then gives the perception that equality of individuals means that each individual must be treated the same as other individuals. But then it becomes relative if equality is different from what is done to the way it is treated, as well as the treatment of similar things in the same way (Hayat, 2015). Related to this, it is explained in Article 20 of the OJK (Financial Services Authority) Regulation Number 77 /POJK.01/2016 concerning Information Technology-Based Lending and Borrowing Services which states that the loan agreement between digital financial service providers and the loan recipient is set out in an electronic document. Thus, it is possible that in an agreement there will be parties who fail to carry out their achievements, or are referred to as defaults. For this reason, in the implementation of Fintech practice, legal protection for both lenders (collectors) and loan recipients is very necessary by complying with the principles of mutual justice.

In assessing a fairness between the parties, in accordance with John Stuart Mill's opinion, he carried out three main steps, namely first, assessing the form of injustice and investigating its general nature; second, investigate feelings related to justice and examine whether these feelings are based on usefulness; third, examine some controversial cases to show that the insistence on justice will not be able to answer the controversy, but only the calculation of benefits can answer it. So that in the end John Stuart Mill can conclude that justice is a name for certain classes of moral rules which highlight the essence of human benefit more closely than and therefore become a more absolute obligation of any other guiding rule of life; and the idea that we know is the essence of the idea of justice, namely a right given to an individual to implement and testify to a more binding obligation.

The injustices referred to by John Stuart Mill include:

a. Separates people from the things over which they are legal;

b. Separates people from those things to which they have moral rights;

c. A person does not allow what he deserves, good for those who act rightly, and bad for those who act wrongly;

d. Differences of faith among individuals;

e. Being half-hearted, for example showing support only as a sweetener on the lips;

f. Threaten or suppress others who are not equal to him. 
The fairness assessment in the discussion of consumer legal protection for the billing mechanism by digital financial service providers in line with Rawls and Ruman's opinion can be formulated in several principles, namely, the principles of rationality, consistency, publicity, and presumption of innocence. The principle of rationality is defined as a principle that provides a paradigm for law properly and correctly in regulating individuals to obey all elements and legal concepts that exist rationally and consciously by leaving all prohibitions in accordance with the provisions of the law itself. The principle of consistency explains that consistency in the law is an obligation for the implementation and application of the law in a fair and wise manner, and the sanctions that follow must also apply equally according to the level of legal behavior. So that in this principle judicial decisions in law that are based on the good for everyone can apply consistently. In the principle of publicity, it means that every violation has provisions in law which have implications for the applicable law enforcement principle, with the reference that there is no violation without the law (nulla crimen sine lege) as the source of the legal system. This principle of publicity is also useful as legal learning for each individual so that it can be studied and obeyed together in all actions and deeds. The principle of presumption of innocence is applied in caution in determining someone as a suspect in an act that is considered to have violated the law. Therefore, it is important to apply the principle of presumption of innocence to suspects to ensure their rights as individuals are not neglected in an effort to uphold justice, in the context of this study there is a set of laws aimed at providing consumer protection. The legal instrument in question is the Law of the Republic of Indonesia Number 8 of 1999 concerning Consumer Protection. In the preamble to the Consumer Protection Law, it is stated that producers must have responsibility for the products or business regulations they apply: "In order to increase the dignity of consumers, it is necessary to increase awareness, knowledge, concern, ability and independence of consumers to protect themselves and to develop responsible business behavior answer" of course by fulfilling the concepts of justice.

\section{Consumer protection}

The term of consumer comes from and is translated from the word consumer, literally meaning the word consumer is (as opposed to producer) everyone who uses goods. The General Indonesian Dictionary defines consumers as opposed to producers, namely users of industrial goods, foodstuffs and so on. Consumers are defined as people or individuals who must be protected as long as they do not have the capacity and act as producers, business actors and or business people. Consumer protection is known to have a broad scope including consumer protection for goods and services, starting from the activity stage to obtain goods and services to the consequences of using these goods and or services.

Consumer protection has been the center of interest in the agenda of policy makers (Gaganis, et al., 2020) and it's attracted researchers to investigate. For example, several reports by the World Bank (2012) and the European Parliament (2014) declare that limited consumer protection in the financial sector parts enhanced the crisis in global financial, while improvements in consumer protection are essential for improved competition, efficiency and access to retail financial markets. Previous studies tried to research the cosumer protection in banking sectors such as Pasiouras (2008) who investigates the impact of consumer protection policies on bank net interest margins around the world, Pitofsky (1977), Kopalle \& Lehmann (2015), World Bank (2014) who force banks to become more efficient and who contend that financial consumer 
protection policies could shift the focus of competition on quality and price. Duke (2009) states that "Trust in the financial system can be regained only if sufficient consumer protections are in place to give borrowers reason to believe they will be treated fairly.

Consumer protection is an integral part of healthy business activities (Hamid, 2017). In healthy business activities there is a balance of legal protection between consumers, business actors and the government, the absence of balanced protection causes consumers to be in a weak position. This weak consumer condition requires protection measures so that consumer rights can be enforced (Hamid, 2017). For this reason, the term consumer protection is defined as all efforts that guarantee legal certainty to provide protection to consumers (Rosmawati, 2018).

In essence, there are two important legal instruments that form the basis of consumer protection policies in Indonesia. First, the 1945 Constitution, as the source of all laws in Indonesia, mandates that national development aims to create a just and prosperous society. The goal of national development is realized through a democratic economic development system so that it is able to grow and develop a world that produces goods and services suitable for consumption by the community. Second, Law Number 8 of 1999 concerning Consumer Protection (hereinafter referred to as UUPK). The enactment of this law provides hope for the people of Indonesia to obtain protection for losses suffered by transactions of goods and services. UUPK guarantees legal certainty for consumers (Ahmad, 2007).

Various literatures found two terms regarding the law relating to consumers, namely consumer law and consumer protection law. Due to the weak position of consumers, they must be protected by law. One of the characteristics, as well as the purpose of the law, is to provide protection to the community, so actually consumer law and consumer protection law are two areas of law that are separated and delimited. The definition of consumer protection is regulated in Article 1 number (1) UUPK, which stipulates that "Consumer protection is all efforts that guarantee legal certainty to provide protection to consumers".

In consumer protection, it is known that it is clearly regulated regarding matters that can protect consumers with laws and regulations, but consumers themselves must also take steps to be able to protect themselves, one of which is being a smart consumer. Smart consumers are consumers who do not only look at the price but also see the value by comparing the benefits obtained (total get) to the price paid (total give). Smart Consumers are consumers who are critical and dare to fight for their rights and obligations. It was further explained that smart consumers are consumers who are able to protect themselves, their families, and the environment from goods and services that are not in accordance with Health, Security, Safety and Environment (K3L) (Situmorang, 2007).

Smart consumer is a term used to denote consumers who understand legal protection who will not be easily influenced by tempting advertisements. In addition, smart consumers are consumers who will not be easily influenced by promises given by sellers, and will not be in a hurry when buying products even though the product is very necessary (Oktaviandi, 2018). It was further explained that smart consumers are usually more thorough and careful before deciding to buy a product so that they can avoid various frauds and avoid disappointment in the future.

In order to become a smart consumer, consumers must strive and enforce their rights and obligations as consumers. The following are the rights and obligations of smart consumers. Smart consumer rights are:

a. Get comfort, security and safety

b. Choose the goods or services to be used

c. Get correct, clear, and honest information about the condition of goods or services 
d. Heard his opinions and complaints

e. Get coaching

f. Treated or served correctly and honestly

g. Get compensation or compensation

The obligations of smart consumers include reading or following instructions/information and usage procedures; have good faith in conducting transactions; pay according to the agreed exchange rate; and follow the efforts of legal settlement of consumer protection disputes.

\section{Economics and Legal Morality}

Law enforcement in modern society is not only defined in a narrow sense but also in a broad sense, as in Indonesia law enforcement is enhanced by human elements and the social environment. Humans must adjust to their social environment, and vice versa, the social environment is filled and influenced by human behavior. Human behavior in society is not free, but is disciplined by a network of rules that exist in society. These rules are signs that bind and limit the behavior of people in society, including law enforcement officials. In a broader sense or law in general is the whole collection of rules or rules in a common life. The whole rule of behavior that applies in a common life that can be enforced with a sanction.

On the other hand, Soedarto (1986) emphasized that law enforcement can be preventive, repressive and curative and can also be applied to the fields of criminal law, civil law and administrative law. Each of these law enforcement systems is supported and implemented by state apparatus or law enforcement officials who have their own rules. Preventive law enforcement is an effort to prevent crime, an effort to keep the person concerned and the community in general from committing a crime. Repressive law enforcement is all actions taken by law enforcement officials after a crime has occurred. Then curative law enforcement is preventive law enforcement in the broadest sense in an effort to overcome crime which is more focused on actions against people who commit crimes (Soedarto, 1986).

Law enforcement does not only include law enforcement but also peace maintenance, because law enforcement is a process of harmonization between values, rules, and real behavior patterns, which aims to achieve peace. The main task of law enforcement is to achieve justice through law enforcement. In the field of law, justice is a duty for the law or is a use of law. Justice as a legal duty is the result of harmonization between legal certainty and legal comparability. Ideally, law is a reflection of the principle of neminem laedere, while proportionality is a reflection of the principle of suum tribuere, namely incommensurability. Each of these two principles is one pole in the image of justice. The principle of neminem laedere is a joint of equality which is shown without exception. The principle of suum cuiqe tribuere is a joint equity that is directed at equating what is the same and distinguishing what is different. In everyday life equity is considered as a specific and concrete thing.

For business people, the principle of neminem laedere and the principle of suum cuiqe tribuere really need to be lived and developed. The principle of comparability and not harming one of the parties in this legal relationship means acknowledging the rights and obligations of each party. These parties are not only business people, but also consumers, the wider community, creditors, and the government. 
For business people there are principles that should be adhered to as ethics, namely (Keraf, 1998):

1. Principle of Autonomy

2. Honesty Principle

3. The Principle of Justice

4. The principle of mutual benefit

5. The principle of moral integrity

\section{Financial Technology}

The term of Fintech is the abbreviation of financial technology and was most probably first mentioned in the early 1990s by Citicorp's chairman John Reed in the context of a newly founded "Smart Card Forum" consortium: "Speaking a language of cooperation between companies and across industries, (...) Citicorp has shed its historical insistence on calling its own technological tune. The harmony emanating from the Smart Card Forum has attracted about 30 dues-payers, including leaders from financial services and high technology. Another 30 have shown an interest in joining. Along with another Citicorp-initiated banking research project called Fintech, it tends to disarm any remaining criticism about Citicorp's being arrogantly out of touch with market preferences"' (Kutler 1993).

Financial technology or Fintech according to Nofie is the implementation and use of technology to improve banking and financial services which are generally carried out by startups using the latest software, internet, communication and computing technology. Digital finance is a system in which financial services are delivered through a digital infrastructure. It diverts from using cash and traditional bank branches, individuals and businesses connected to digital payment infrastructure via mobile phones, computers and point-of-sales devices (Anita, et al., 2019).

Fintech describes the interaction between finance and technology. Market participants have offered innovative technology solutions for traditional financial services. Financial Technology (Fintech) is financial products and services through a combination of technology platforms and innovative business models ( $\mathrm{Lu}, 2017)$. In Indonesia, there are 4 main categories of Fin-tech, namely (1) payment, clearing, settlement; (2) deposit, loan, capital increase; (3) market provision, and (4) investment \& risk management.

According to The National Digital Research Center (NDRC), in Dublin, Ireland, Fintech is an "innovation in financial services" or "innovation in Fintech financial services" as an innovation in the financial sector that gets a touch of modern technology. According to IOSCO (2017) the term Fintech is used to describe various innovative business models and emerging technologies that have the potential to transform the financial services industry (Wulan, 2017).

Fintech maps out eight categories, there are payments, insurance, planning, lending and crowdfunding, blockchain, trading and investment, data and analytics, and security. Fintech is known to be nothing new in the financial industry. The journey of Fintech began in the 1950s but if it is recalled, since 1865 Fintech has begun. This can be seen in the Figure below (Santi., 2017). 


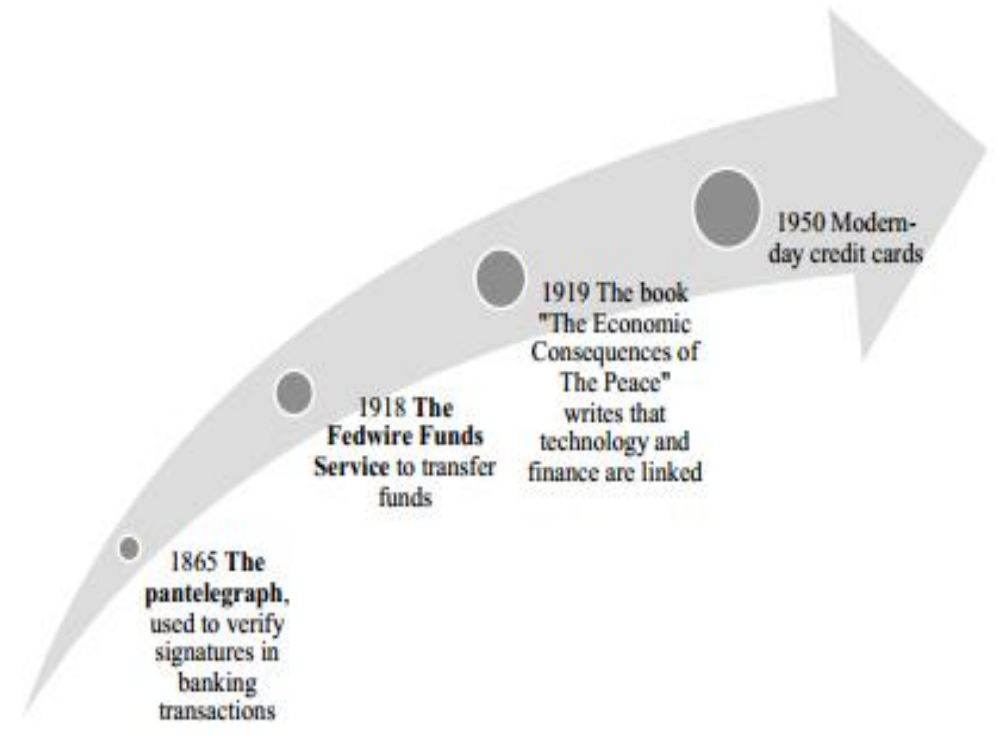

\section{Picture 2. The History of Financial Technology}

Financial Technology (Fintech) is defined as a technology-based business that competes with and or collaborates with financial institutions. The Fintech process ranges from creating software to process activities that are usually carried out by financial institutions to improving the consumer experience and streamlining the payment process to be more efficient, or enabling consumers to meet their financial needs (saving, investing, making payments (Ernama et al., 2017).

Financial technology (Fintech) is growing rapidly along with the advancement of internet technology and gadgets such as mobile phones, smartphones, PCs, tablet PCs, netbooks and notebooks. Armed with gadgets and the internet, everyone can access various kinds of applications that can be used to simplify human life. The payment system can now be done via the internet using an electronic wallet (e-wallet) application. The public can also access loan funds through the PM-Financial Technology service company website without going through banks or financial institutions (Hariyani \& Serviyani, 2017). Financial transactions through Fintech include payments, investments, lending money, transfers, financial plans and comparisons of financial products. Some Fintech companies that already exist in Indonesia today, for example, Check Aja, Friends Money, Borrow, Check Premiums, Bareksa, Kejora, Doku, Veritrans, Kartuku (Ernama, et al., 2017).

The regulation and supervision of the tekfn/Fintech business in Indonesia is carried out by two independent state institutions, namely Bank Indonesia (BI) and the Financial Services Authority (OJK). BI is in charge of regulating and supervising the service business of "Financial Technology-based Payment System" which publishes "electronic wallet" or e-wallet applications. An electronic wallet is a virtual payment facility that can be used to store data on cash, debit cards, credit cards and electronic money (Hariyani \& Serviyani, 2017). 


\section{Digital Documents}

Information technology that is growing rapidly has led to the emergence of document digitization. Documents that were previously only physical documents (hard files), have now developed into digital documents. In digital documents, electronic document systems are known as any manual system that stores documents in terms of using the public structure of how to store documents, which include Cabinet, Drawer, and Folder, where files are stored in them, Files, and finally Documents which are jobs. scanning them using Scanner (Al Shobaki, et al., 2017).

Digital documents are archives of files contained in electronic storage media, which are generated, communicated, stored and/or accessed using electronic equipment (Rifauddin, 2016), therefore these digital documents are also generally known as electronic documents. According to Article 1 Paragraph 4 of Law No. 11 of 2008 concerning Information and Electronic Transactions explains that,

Electronic Document is any Electronic Information that is created, forwarded, sent, received, or stored in analog, digital, electromagnetic, optical, or similar forms, which can be seen, displayed, and/or heard through a Computer or Electronic System, including but not limited to in writing, sound, pictures, maps, designs, photographs or the like, letters, signs, numbers, Access Codes, symbols or perforations that have meaning or meaning or can be understood by people who are able to understand them.

Electronic documents are recognized as valid legal evidence, since the enactment of Law Number 11 of 2008 concerning Electronic Information and Transactions which in article 5 paragraph (1) states that "Electronic Information and/or Electronic Documents and/or their printed results are evidence valid law". In Article 5 Paragraph 2 of Law Number 11 of 2008 concerning Information and Electronic Transactions it is also explained that electronic information and or documents are an extension of legal evidence in accordance with the applicable procedural law in Indonesia.

Furthermore, in Article 5 Paragraph 3 of Law Number 11 of 2008 concerning Information and Electronic Transactions it is explained that electronic documents can be said to be valid if "......using the Electronic System in accordance with the provisions stipulated in this Law". The provisions according to Article 5 Paragraph 4 of Law Number 11 of 2008 concerning Electronic Information and Transactions do not apply to:

(1). Letter which according to the law must be in written form; and

(2). Letter and its documents which according to the law must be made in the form of a notarial deed or a deed made by the official making the deed.

Electronic information and or documents according to Article 6 of Law Number 11 of 2008 concerning Electronic Information and Transactions can be "...considered valid as long as the information contained therein can be accessed, displayed, guaranteed for its integrity, and can be accountable so as to explain a situation". Thus, it can be said that electronic documents can be used as evidence, if they meet the following requirements:

(1). Accessible;

(2). Displayed;

(3). Its integrity is guaranteed;

(4). Can be accounted for so as to explain a situation.

The criteria that must be considered in the use of electronic documents as evidence that must be met are (Tarigan et al., 2016):

(1). Allowed by law to be used as evidence. 
(2). Reliability, namely the validity of the evidence can be trusted.

(3). Necessity, namely evidence that is needed to prove a fact.

(4). Relevance, namely the evidence submitted has relevance to the facts to be proven.

Documents relate to evidence and evidence implies facts.

\section{RESEARCH METHOD}

Legal research methods are research that must be distinguished from other social science research, because each science has its own method. (Ahmad, 2009) As explained by H.J. van Eikema Hommes who stated that every science has its own method, so it is not possible to do uniform methods for all fields of science. Therefore, research methods and social research methods cannot be used in legal research. The research method applied in this study is a normative legal research method. The research is said to be juridical normative because it intends to conduct a study and analyze the substance of the legislation on the subject matter or legal issue in its consistency with existing legal principles (Marzuki 2011). The emphasis of normative juridical research, in accordance with the distinctive character of legal scholarship, lies in the study of law or legal studies of positive law, which includes three layers of legal scholarship, consisting of the study of legal dogmatics, legal theory, and legal philosophy. At the level of legal dogmatics, the study is carried out on identification in positive law, especially legislation. Meanwhile, at the level of legal theory, a review of the theories that can be used is carried out.

\section{Research Type}

As with the determination of the research method applied, the type of legal research is also not the same as other types of research, due to differences in context and layers or levels. This type of legal research is a process to find the rule of law, legal principles, and legal doctrine in order to answer the legal issues faced. This is in accordance with the character of legal research which is prescriptive, and not descriptive, so that legal research is carried out to produce arguments, theories or new concepts as prescriptions in solving problems at hand (Ahmad, 2009).

Thus, it can be explained that this type of research is a prescriptive type of research by combining doctrinal, reform-oriented, and theoretical research types. The selection of this type of research is based on the stated research objectives, namely to examine, analyze, and find legal norms related to consumer legal protection for billing mechanisms by digital financial service providers.

\section{Problem Approach}

The problem approach in legal research helps researchers to obtain information from various aspects regarding the issue that is being tried to answer. The approaches used in legal research are the statute approach, the conceptual approach and the comparative approach, with the following details:

(1). The problem approach used to examine and analyze legal issues regarding the nature of online loans in Indonesian legal regulations is a statutory approach, a conceptual approach. The statute approach is carried out by analyzing the laws and regulations, including the Law of the Republic of Indonesia Number 10 of 1998 concerning Amendments to Law Number 7 of 1992 concerning Banking, Regulation of the Financial Services Authority Number 77 / 
POJK .01/2016 concerning Information Technology-Based Lending and Borrowing Services, Bank Indonesia Regulation Number 18/40/Pbi/2016 concerning the Implementation of Payment Transaction Processing, and Bank Indonesia Regulation Number 19/12/PBI/2017 concerning the Implementation of Financial Technology.

(2). Meanwhile, the conceptual approach departs from the views of the doctrines in the science of law. Conceptual approach is done by studying the views, theories and doctrines in the science of law. This approach is used to find ideas that give birth to legal understandings or concepts, because in normative research, it means having to look at applicable legal norms, both from civil procedural law norms, civil law, customary law and related ones, regardless of the prevailing norms then there is no this study. In this study, the nature of online loans in Indonesian legal regulations will also be studied with the economic theory of transactions and banking.

(3). The problem approach used to examine and analyze legal issues regarding the philosophy of consumer protection in online lending practices in Indonesia is a statutory approach, a conceptual approach and a comparative approach. The statutory approach is carried out by analyzing the laws and regulations, including the Law of the Republic of Indonesia Number 8 of 1999 concerning Consumer Protection, Law Number 5 of 1999 concerning the Prohibition of Monopolistic Practices and Unfair Business Competition, Law of the Republic of Indonesia Number 30 of 1999 concerning Arbitration and Alternative Dispute Resolution, Law of the Republic of Indonesia Number 19 of 2016 concerning Amendments to Law Number 11 of 2008 concerning Information and Electronic Transactions Government Regulation of the Republic of Indonesia Number 58 of 2001 concerning Guidance and Supervision of the Implementation of Consumer Protection and Regulation of the Financial Services Authority Number: 1/Pojk.07/2013 concerning Consumer Protection in the Financial Services Sector.

Meanwhile, the conceptual approach departs from the views of the doctrines in the science of law. Conceptual approach is done by studying the views, theories and doctrines in the science of law. This approach is used to find ideas that give birth to legal understandings or concepts, because in normative research, it means having to look at applicable legal norms, both from civil procedural law norms, civil law, customary law and related ones, regardless of the prevailing norms then there is no this study. In this study, the philosophy of consumer protection in online lending practices in Indonesia will also be studied with the theory of justice, consumer protection theory, civil law theory and agreement theory.

(1). Legal Material

This study uses primary legal materials and secondary legal materials as follows:

a. Primary Legal Material

Sources of primary legal materials consist of the main components in normative research, namely authoritative legal materials including statutory regulations, official records or minutes in the formation of legislation or court decisions, including:

1) Law of the Republic of Indonesia Number 10 of 1998 concerning Amendments to Law Number 7 of 1992 concerning Banking, State Gazette of the Republic of Indonesia of 1998 Number 182, Supplement to the State Gazette of the Republic of Indonesia Number 3790.

2) Law of the Republic of Indonesia Number 8 of 1999 concerning Consumer Protection, State Gazette of the Republic of Indonesia of 1999 Number 42. 
3) Law Number 5 of 1999 concerning Prohibition of Monopolistic Practices and Unfair Business Competition, State Gazette of the Republic of Indonesia of 1999 Number 33, Supplement to the State Gazette of the Republic of Indonesia Number 3817.

4) Law of the Republic of Indonesia Number 30 of 1999 concerning Arbitration and Alternative Dispute Resolution, State Gazette of the Republic of Indonesia Number 138 of 1999, Supplement to the State Gazette of the Republic of Indonesia Number 3872.

5) Law of the Republic of Indonesia Number 19 of 2016 concerning Amendments to Law Number 11 of 2008 concerning Information and Electronic Transactions, State Gazette of the Republic of Indonesia of 2016 Number 251, Supplement to the State Gazette of the Republic of Indonesia Number 5952.

6) Government Regulation of the Republic of Indonesia Number 58 of 2001 concerning Guidance and Supervision of the Implementation of Consumer Protection, State Gazette of the Republic of Indonesia of 2001 Number 103, Supplement to the State Gazette of the Republic of Indonesia Number 4126.

7) Financial Services Authority Regulation Number: 1/POJK.07/2013 concerning Consumer Protection in the Financial Services Sector, State Gazette of the Republic of Indonesia Year 2013 Number 118.

8) Financial Services Authority Regulation Number 77/POJK.01/2016 concerning Information Technology-Based Borrowing-Lending Services, State Gazette of the Republic of Indonesia Year 2016 Number 324.

9) Bank Indonesia Regulation Number 18/40/PBI/2016 concerning Implementation of Payment Transaction Processing, State Gazette of the Republic of Indonesia Year 2016 Number 236, Supplement to State Gazette of the Republic of Indonesia Number 5945.

10) Bank Indonesia Regulation Number 19/12/PBI/2017 concerning Implementation of Financial Technology, State Gazette of the Republic of Indonesia Year 2017 Number 245, Supplement to State Gazette of the Republic of Indonesia Number 6142.

b. Secondary Legal Material

The secondary legal materials in this study are textbooks containing the basic principles of legal science, previous research journals that are relevant to the research topic. Secondary legal materials include publications on law that are not official documents such as textbooks, legal dictionaries, legal journals and commentaries on court decisions.

(1) Legal Materials Collection Procedure

The collection of legal materials is carried out through the documentation method in two ways, namely an inventory of primary legal materials and library research on secondary legal materials. Inventory of primary legal materials is carried out through a positive legal inventory related to research problems. While the literature search is carried out by conducting a literature study on secondary legal materials, namely supporting literature related to the legal issues observed in this study.

(2). Legal Material Analysis

The legal materials that have been collected are then identified and classified according to their source and hierarchy. After all legal materials are organized, identified, classified, and systematized, then they are studied or analyzed using legal reasoning with a deductive-inductive method and/or interpretation is carried out to be able to solve or find answers to research problems based on doctrines, theories, principles, or legal principles that according to the theory used in this study. 
The inductive method is a method that analyzes the minor premise (legal facts) followed by analysis on the major premise (law rules). This inductive method explains or solves legal issues by moving from the formulation of legal facts first, then relating them to the legal rules contained in the law. While the deductive method is a research method that starts from the major premise (rule of law) to the minor premise (legal facts) to draw conclusions. Through deductive reasoning, this study explains and solves legal issues by departing from the legal rules contained in the law and linked to the legal facts.

Through prescriptive analytical techniques, this study seeks to find answers to the observed legal issues, namely consumer legal protection for billing mechanisms by digital financial service providers using an approach from legal, sociological, institutional, and role aspects, through a legal approach., and conceptual. Thus, legal facts can be interpreted and linked to the rule of law and vice versa, which can then be connected to the preparation of prepositions in response to the observed legal issues.

\section{DISCUSSION}

The rapid growth of $\mathrm{P} 2 \mathrm{P}$ lending in the last 3 years shows the high public demand for online loans. The reason why borrowers make loans through $\mathrm{P} 2 \mathrm{P}$ is because it is difficult for most Indonesians to access formal financial services with many administrative requirements. Ease of borrowing is one of the advantages of Fintech lending compared to other banks Its formal nature, Within hours the funds can be disbursed without the borrower having to come directly to the branch office, of course this is an interesting thing and much in demand by the Indonesian people in general, digital footprint is used as a substitute physical documents for verification and use of third party data to determine the eligibility of potential borrowers.

However, from this, there are problems that are still being debated, including the growth of illegal financial technology. This is due to the potential of the market itself in Indonesia which is quite large for online loans. many Indonesians turn to illegal technology finance because the process is easier and faster. If we look at this problem, illegal technology finance is a human rights problem and a national problem, of course, it is against the principles of justice. Misuse of consumer data without consent, by accessing a mobile device to then conduct an intimidating collection, means that it can reveal personal data such as crawling contact data to disseminating information.

Standard contracts set by financial technology companies in Indonesia are not in accordance with the principles of justice and equality of rights in the consumer protection law such as high interest without restrictions that have not been regulated, collections are not made only through loans and emergency contacts. being contacted from their mobile device, threats of sexual harassment, Exposing personal data such as photos, acquisition of personal data from mobile devices, unclear contact and office addresses, unclear administration fees, changing the name of the application without notifying the customer, the loan has paid the debt but is still being billed because it has not been reflected in the application. Problems related to human rights also appear new problems related to the state according to researchers such as the number of illegal financial technologies that can be used as money laundering which may be able to fund terrorism, misuse of consumer data, loss of potential tax revenue, there are still many people who do not know about online loans, and exploited by financial technology, the Indonesian people are victims of unethical collections so that the State is disadvantaged from many sides. 
Basically, in the dispute resolution process, both regulated in the Consumer Protection Act and in the Arbitration and Alternative Dispute Resolution Act, the goal is to achieve legal certainty, justice and provide solutions for the common good with the principles of Win win Solution.

In practice, dispute resolution between consumers and business actors through non-litigation channels is one of the best ways to do this considering the position of business actors and consumers both have interests. From the perspective of business actors themselves, dispute resolution through out of court is the best way to resolve business problems quickly and maintain a good business reputation. In addition, from the consumer's perspective, dispute resolution through out-of-court channels is the most appropriate step considering that many consumers or the Indonesian people in general are still afraid to settle cases through the courts.

The results obtained by the author found similarities between dispute resolution from the perspective of the Consumer Protection Act with the arbitration protection law and alternative dispute resolution which both provide legal certainty to the parties. In Indonesia itself, many business actors do not use the basis of Consumer Protection as a reference in making their business contracts, but they use the Arbitration and Dispute Resolution Law as a solution taken to solve their problems. According to the researcher, this is certainly not a problem for the goals to be achieved because in a business relationship, of course, the parties involved want to reach a mutual agreement in the absence of the most disadvantaged or benefited party in a problem. field that business actors are still using dispute resolution according to the Law on Arbitration and Alternative Dispute Resolution, so it is necessary to include this study in further research.

So that there is a clear correlation between morality and law enforcement for business actors. Morality is an important component in doing business/business. The importance of morality is related to the purpose of business relations between consumers and business actors by introducing them according to the situation and conditions as well as applicable legal norms. Legal concretization for business people occurs when there are violations of applicable regulations.

\section{REFERENCES}

\section{Legal References}

Law of the Republic of Indonesia Number 8 of 1999 concerning Consumer Protection, State Gazette of the Republic of Indonesia of 1999 Number 42.

Law of the Republic of Indonesia Number 10 of 1998 concerning Amendments to Law Number 7 of 1992 concerning Banking, State Gazette of the Republic of Indonesia of 1998 Number 182, Supplement to the State Gazette of the Republic of Indonesia Number 3790.

Law of the Republic of Indonesia Number 19 of 2016 concerning Amendments to Law Number 11 of 2008 concerning Information and Electronic Transactions in the State Gazette of the Republic of Indonesia of 2016 Number 251, Supplement to the State Gazette of the Republic of Indonesia Number 5952.

Government Regulation of the Republic of Indonesia Number 58 of 2001 concerning Guidance and Supervision of the Implementation of Consumer Protection and Regulation of the Financial Services Authority Number: 1/POJK.07/2013 concerning Consumer Protection of the Financial Services Sector. State Gazette of the Republic of Indonesia Year 2001 Number 103, Supplement to State Gazette of the Republic of Indonesia Number 4126. 
Financial Services Authority Regulation Number: 1/POJK.07/2013 concerning Consumer Protection in the Financial Services Sector, State Gazette of the Republic of Indonesia Year 2013 Number 118.

Financial Services Authority Regulation Number 77/POJK.01/2016 concerning Information Technology-Based Borrowing-Lending Services, State Gazette of the Republic of Indonesia Year 2016 Number 324.

Bank Indonesia Regulation Number 18/40/PBI/2016 concerning Implementation of Payment Transaction Processing of the State Gazette of the Republic of Indonesia Year 2016 Number 236, Supplement to the State Gazette of the Republic of Indonesia Number 5945.

Bank Indonesia Regulation Number 19/12/PBI/2017 concerning Implementation of Financial Technology, State Gazette of the Republic of Indonesia Year 2017 Number 245, Supplement to State Gazette of the Republic of Indonesia Number 6142.

Law of the Republic of Indonesia Number 19 of 2016 concerning Amendments to Law Number 11 of 2008 concerning Information and Electronic Transactions in the State Gazette of the Republic of Indonesia of 2016 Number 251, Supplement to the State Gazette of the Republic of Indonesia Number 5952.

Law Number 5 of 1999 concerning Prohibition of Monopolistic Practices and Unfair Business Competition, State Gazette of the Republic of Indonesia of 1999 Number 33, Supplement to the State Gazette of the Republic of Indonesia Number 3817.

Law of the Republic of Indonesia Number 30 of 1999 concerning Arbitration and Alternative Dispute Resolution, State Gazette of the Republic of Indonesia of 1999 Number 138, Supplement to the State Gazette of the Republic of Indonesia Number 3872.

\section{Articles \& Books}

Al Shobaki, M.J., Samy S., Naser, A., \& Kassab, M.K.I. The Reality of the Application of Electronic Document Management System in Governmental Institutions-an Empirical Study on the Palestinian Pension Agency. International Journal of Engineering and Information Systems. 2017.

Ahmad, M. Perlindungan Konsumen di Indonesia. Jakarta: Media Indonesia. 2007.

Anita, Zulaikha, S., Rofiah, K. \& Pertiwi, R.S. Legal Protection of Lenders in the Implementation of Financial Technology Based on Peer to Peer Lending, The 2nd International Conference on Islamic Economics, Business, and Philanthropy (ICIEBP) Theme: "Sustainability and Socio Economic Growth". 2019; 1308-1309.

Duke, E.A. The systemic importance of consumer protection. Speech at the 2009 Community Development Policy Summit, Cleveland, Ohio. 2009. Available at: https://www.bis.org/review/r090615d.pdf

European Parliament. Consumer Protection Aspects of Financial Services. Directorate P/A/IMCO/ST/2013-07. 2014.

Fenwick, M., McCahery, J.A., \& Vermeulen, E.P.M. Fintech and the financing of SMEs and entrepreneurs: From crowdfunding to marketplace lending. In The Economics of Crowdfunding: Startups, Portals and Investor Behavior. 2018; 103-129. Palgrave Macmillan Ltd.. https://doi.org/10.2139/ssrn.2967891, https://doi.org/10.1007/978-3-319-66119-3_6

Gaganis, C., Galariotis, E., Pasiouras, F. \& Staikouras, C. Bank profit efficiency and financial consumer protection policies. Journal of Business Research. 2020; 118:98-116.

Gai, K., Qiu, M. \& Sun, X. A survey on FinTech. Journal of Network and Computer Applications. 2018; 103:262-273. 
Gomber, P., Koch, J.A. \& Siering, M. (Digital Finance and FinTech: current research and future research directions). Journal of Business Economics. 2017;87(5):537-580.

Kutler, J. Citibank is shedding individualistic image. Am Bank. (1993). https://www.americanbanker.com/opinion/friday-flashback-didciti-coin-the-term-fintech

Lee, I. \& Shin, Y.J. Fintech: ecosystem, business models, investment decisions, and challenges. Bus. Horiz. 2018; 61(1):35-46.

Ma'arif, S. and Tanjung, H. Manajemen Operasi, Edisi Pertama. PT. Grasindo, Jakarta, 2003; 36-37. 2017.

Hamid, A.H. Hukum Perlindungan Konsumen Indonesia. Makassar: CV. SAH MEDIA.

Hayat. Keadilan sebagai Prinsip Negara Hukum: Tinjauan Teoretis dalam Konsep Demokrasi. Padjadjaran Jurnal Ilmu Hukum. 2015; 2:392.

Hariyani, I., \& Serfiyani, C.Y. Perlindungan Hukum dan Penyelesaian Sengketa Bisnis Jasa PM-Tekfin (Pinjam Meminjam Online). Jurnal Legislasi Indonesia. 2017; 14:3.

Keraf, A.S. Etika Bisnis dan Relevansinya. Yogyakarta, Kanisius. 1998; 74-49.

Kopalle, P.K. \& Lehmann D.R. The Truth Hurts: How Customers May Lose From Honest Advertising. International Journal of Research in Marketing. 2015; 32(3):251-262.

Lu, L. Financial Technology and Challenger Banks in the UK: Gap Fillers or Real Challengers?. Thomson Reuters (Professional) UK Limited and Contributors. 2017; 7:274.

Marzuki, P.M. Penelitian Hukum. Jakarta, Kencana Prenada Media Group. 2011.

Muaziz, M.H. \& Busro, A. Pengaturan Klausula Baku Dalam Hukum Perjanjian Untuk Mencapai Keadilan Berkontrak. Jurnal Law Reform Program Studi Magister Ilmu Hukum. 2015; 11(1):75.

Nurhafni \& Bintang, S. Perlindungan Hukum Konsumen Dalam Perjanjian Baku Elektronik Consumer Law Protection In Electronic Standard Agreement. Kanun Jurnal Ilmu Hukum. 2018; 20(3):474.

Oktaviandi, R. Strategi Komunikasi Dinas Perindustrian Perdagangan Koperasi Dan UKM Provinsi Kalimantan Timur Dalam Mensosialisasikan Konsumen Cerdas Di Kota Samarinda. eJournal Ilmu Komunikasi. 2018.

Pasiouras, F. International evidence on the impact of regulations and supervision on banks' technical efficiency: an application of two-stage data envelopment analysis. Review of Quantitative Finance and Accounting. 2008; 30:187-223.

Pitofsky, R. Beyond Nader: Consumer Protection and the Regulation of Advertising. Harvard Law Review. 1977; 90:661-701.

Pohan, N.W.A., Budi, I. \&Suryono, R.R. 2019. Borrower sentiment on P2P lending in Indonesia based on google playstore reviews. Sriwijaya International Conference of Information Technology and its Applications. Siconian, 2019; 17:17-23.

Pryanka, A. Ini Tiga Acuan Dalam Kode Etik Industri Fintech Lending. Retrieved from Republika.co.id website. 2018. https://www.republika.co.id/berita/ekonomi/keua ngan/18/08/23/pdwmum370-ini-tiga-acuan-dalam-kode-etik-industri-fintech-lendi ng.

Rawls, J. A Theory of Justice:Revised Edition. United States of America, Harvard University Press. 1999.

Rifauddin, M. Pengelolaan Arsip Elektronik Berbasis Teknologi, Khizanah Al-Hikmah. 2016; 4(2):171. 2018.

Rosmawati. Pokok-pokok Hukum Perlindungan Konsumen. Depok, Prenamedia Group. 
Santi, E. Pengawasan OJK Terhadap Fin-Tech (POJK No. 77/ POJK.01/ 2016). Diponegoro Law Journal. 2017; 6(3):2.

Sen, A. The Idea Of Justice, London, Penguin Books. 2010.

Setyawati, D.A. Perlindungan Bagi Hak Konsumen Dan Tanggung Jawab Pelaku Usaha Dalam Perjanjian Transaksi Elektronik. Syiah Kuala Law Journal. 2017; 1(3):36.

Situmorang, S.H. Studi Kelayakan Bisnis: Buku 1. Medan, USU Press. 2007.

Soedarto. Kaplta Selekta Hukum Pidana. Bandung, Alumni. 1986.

Suryono, R.R., Purwandari, B. \& Budi, I. Peer to peer $(P 2 P)$ lending problems and potential solutions: a systematic literature review. Procedia Computer Science. 2019; 161:204214.

Wang, G.R. \& Ong, O.Y.B. Analysis the use of P2P lending mobile applications in Indonesia. J. Phys. Conf. 2019.

World Bank. Good Practices for Financial Consumer Protection. 2012.

World Bank. Global survey on consumer protection and financial literacy: oversight frameworks and practices in 114 economies. Washington DC. 2014.

Wulan, V.R. Financial Technology (Fintech) A New Transaction In Future. Journal of Electrical Engineering and Computer Sciences 2017; 2(1):2528:0260.

Zulham. Hukum Perlindunga Konsumen Edisi Revisi. Jakarta, Kencana. 2013.

\section{Website}

https://www.ojk.go.id/id/kanal/iknb/financial-technology/Pages/Penyelenggara-FintechLending-Terdaftar-dan-Berizin-di-OJK-per-4-Mei-2021.aspx

https://www.kominfo.go.id/content/detail/27753/lega-akhirnya-kementerian-kominfoblokir-empat-ribu-fintech-ilegal/0/sorotan_media 